\title{
Physichochemical Properties and Trace Elements of Soils in Mambilla Plateau of Northeastern Nigeria
}

\author{
Isaac Ernest ${ }^{1}$, Maina Humphrey Mayi ${ }^{2}$, Donatus Raymond Bwano ${ }^{3,}$, , Riki Yohanna Emmanuel ${ }^{4}$, \\ Joseph Bala ${ }^{2}$
}

${ }^{1}$ Department of Chemistry, Taraba State University, Jalingo, Nigeria

${ }^{2}$ Department of Chemistry, Modibbo Adama University of Technology, Yola, Nigeria

${ }^{3}$ Department of Chemical Sciences, Federal University Wukari, Wukari, Nigeria

${ }^{4}$ Department of Basic Sciences, College of Agriculture, Jalingo, Nigeria

Email address:

donatus_r28@yahoo.com (D. R. Bwano)

${ }^{*}$ Corresponding author

\section{To cite this article:}

Isaac Ernest, Maina Humphrey Mayi, Donatus Raymond Bwano, Riki Emmanuel Yohanna, Joseph Bala. Physichochemical Properties and Trace Elements of Soils in Mambilla Plateau of Northeastern Nigeria. World Journal of Applied Chemistry. Vol. 3, No. 3, 2018 , pp. 72-82. doi: $10.11648 /$ j.wjac.20180303.11

Received: June 6, 2018; Accepted: August 29, 2018; Published: October 13, 2018

\begin{abstract}
The soil samples from Mambila Plateau were analyzed to determine the physicochemical properties of elements present by energy dispersive X-Ray Fluorescence. The physical and chemical parameters determined were colour, $\mathrm{pH}$, electrical conductivity, specific gravity and elemental identifications of $\mathrm{Cr}_{2} \mathrm{O}_{3}, \mathrm{CuO}, \mathrm{NiO}$ and $\mathrm{V}_{2} \mathrm{O}_{5}$ respectively. The $\mathrm{pH}$ values for soils of the study area are high between 3.96-4.30 being acidic, electrical conductivity values ranged from $81.79-$ $238 \mathrm{mS} / \mathrm{cm}$ with higher electrical conductivity value at $\mathrm{N}_{1}$ having $238 \mathrm{mS} / \mathrm{cm}$ and lower electrical conductivity at $\mathrm{S}_{1} 81.79$ $\mathrm{uS} / \mathrm{cm}$ respectively. The soil are yellow, red and gray; with hue steps of 2.5YR, 5YR, 7.5YR, and 10YR, a step values between 3-7 and the chroma range of 1- 6. The specific gravity which also is the relative density range from $2.00-2.50$. The percentage elemental contents identified for trace elements decreased in the order $\mathrm{V}_{2} \mathrm{O}_{5}>\mathrm{Cr}_{2} \mathrm{O}_{3}>\mathrm{NiO}>\mathrm{CuO}$. The highest percentage concentration of element found was $\mathrm{V}_{2} \mathrm{O}_{5}$ at $\mathrm{N}_{4} 0.29 \%$ while, $\mathrm{CuO}$ showed minimum concentration of $0.01 \%$. The entire soils indicated high acidity levels due to the $\mathrm{pH}$ results tested, with spatial variation of the elements oxides contents higher at $\mathrm{N}_{1}, \mathrm{~N}_{2}$, $\mathrm{N}_{3}, \mathrm{~N}_{4}$, and decreasing through $\mathrm{E}_{1}, \mathrm{E}_{2}, \mathrm{E}_{3}$ and $\mathrm{E}^{4}$ to $\mathrm{S}_{1}, \mathrm{~S}_{2}, \mathrm{~S}_{3}$ and $\mathrm{S}_{4}$ at lower concentrations.
\end{abstract}

Keywords: Mambilla, Physicochemical, Trace Element, Soil, Standard Notation, Northeastern Nigeria

\section{Introduction}

Soil is the topmost layer of the earth surface that is diverse in complexity with mixtures of minerals and organic materials, aqueous and gaseous components, which are capable of supporting plants and animals' life. [1-3]. Soil survey generates host of information on soils and other environmental factors. In the past, these soils information were primarily used to develop land use plans, to support increased crop production. However, the use of soil information for non-agricultural purpose is on the increased. There is increased awareness of the use of soil information as an essential input in the evaluation, prediction of minerals deposits and effect of land use on environmental degradation and sustainability. In Nigeria, like most developing countries, one primary constraint to sustainable and successful agricultural programme is the lack of knowledge about the soil resources and how to manage them. [4]. There is increasing need for information on soils as a means to its maximum uses, greater and healthy food production. The variation in soil properties due to land use and management, and their consequences to the production capacity; has been subject of research in the past for a range of climatic and edaphic conditions. [5]. A study by Amuyou et al. [6] on spatial variability of soil properties, observed topographic influence over the distribution of soil physical and chemical properties such as $\mathrm{pH}$, organic carbon, exchangeable elements, cation exchange capacity and total nitrogen. [6]. 
The assessment of the variation in soil topography informed the soil profile development, consequently understanding the role of these properties is relevant in assessing productive value of soil, and developing strategies for its conservation under different agricultural systems. [7]. In the past, agricultural system in Nigeria relied mainly on shifting cultivation to maintain the fertility of the soil through organic matter and plant nutrient build up during fallow periods. However, due to population pressure and increased in urbanization being brought under cultivation, the fallow periods are being systematically reduced [8]. Products of soil are also being lost through erosion, desertification and deforestation. Consequently, output per hectare, especially of food crops, is declining hugely with continued cultivation which depletes soil nutrients. All these factors have seriously contributed to the current high level of poverty playing the use of many lands today. According to Stolt et al. [9] the spatial variability of elements is universal to all soil and can have many possible sources due to differences in weathering rates, lithology, topography or hydrology. Studies by Amoyou et al. and Mokuna [6, 10], has observed that systematic variability of the soil is a function of topographic sequence characteristics of the soil; landforms, geomorphic elements, soil forming factors and interactions of these three factors. The weathering processes occur over an extended period of time resulting in soil that varies from the original rock or sediment in its physical and chemical properties. In addition, organic matter from decaying vegetation and microorganisms is added to the soil and pronounced vertical arrangement of layers develops in the soil, known as a soil profile. Thus soil profile extends from the surface downward to the un-weathered soil parent material. Soils contained different harmful constituents, elemental and biological, including heavy metals and trace metals, therefore referred to as just metals. [11]. The total metal content of soils is important for many geochemical applications, but usually the speciation (bioavailability) of these metals is more of an interest agriculturally in terms of what is biologically extractable. [11]. Soil differs from its parent rock due to interaction between lithosphere, hydrosphere and the biosphere. The material from which soil forms is called parent material. It includes: weathered primary bedrock, secondary materials transported from other locations, e.g. colluviums and alluvium deposits that are already present but mixed or altered in other ways-old soil formations, organic material including peat or alpine humus, and anthropogenic materials like landfill or mine waste. The deeper sections of the soil profile may have materials that are relatively unchanged from when they were deposited by water, ice or wind. Weathering is the first stage in the transformation of parent material into soil material. In soil forming from bedrock, a thick layer of weathered material called saprolite may form. Saprolite is the result of weathering processes that include: hydrolysis, chelating from organic compounds, hydration, solution of minerals by water, and physical processes that include freezing and thawing or wetting and drying. [12, 13]

The Mambilla Plateau is selected for the study, in view of its peerless splendor and natural architecture and landscaping with hilly deep gorges. The climate of the Plateau is comparatively cold, associated with frequent and heavy rainfall due to orographic activities on the Plateau. The vegetation on the plateau comprises low grasses with trees being noticeably absent except for manmade forest $[14,15]$. There was no known research conducted to assess the nutrient and pollutant elements in this abundant tourism potential. As at the time of this study Sardauna Local Government Area of Taraba State has no established information on status as well as the variability of soil physical and chemical properties in this natural architecture and landscaping of the terrain. This study was set to fill the gap and initiate further quest for mineral exploration and toxicity studies of soils in the area. The results of this study will ascertain the authenticity of high speculation of mineral deposit including gold, silver, and precious stones in the Plateau. The result from this research would assist in exploiting, correcting and preserving the enriching features of the plateau for the maximum agricultural and mineral utilization, enhancement of revenue earnings for the state in particular and the country at large. The energy dispersive Xray fluorescence (EDXRF) is a multi-element analytical instrument that is highly sensitive Virendra and Agrawal. [16]. It will be used to achieve this analytical task.

\section{Materials and Methods}

\subsection{Materials (Instruments/Apparatus)}

Munsell soil colour chart, funnels, beakers, filter papers, $2 \mathrm{~mm}$ sieve, glass rod, volumetric flask and analytical balance, measuring cylinder, pestle and mortar, Sensio $\mathrm{pH}$ meter, Sensio Electrical conductivity meter, and MiniPal4 energy-dispersive $\mathrm{x}$-ray fluorescence (EDXRF) spectrometer model PW 4052/47B. Additionally the following tools were used: cutlass, hoe, measuring rule, clean dry polyethylene bags and corer.

\subsection{The Study Area}

The study area, Mambila Plateau is found in the southeastern part of Taraba state of Nigeria in Sardauna Local Government Area. It measures about $96 \mathrm{~km}(60 \mathrm{~m})$ along its curved length, it is $40 \mathrm{~km}(25 \mathrm{~m})$ wide and bounded by an escarpment that is about $900 \mathrm{~m}(2,953 \mathrm{ft})$ high in some places. The plateau covers an area of over 9,389 square kilometers $(3,625$ square meters) with daytime temperature that hardly exceeds $25^{\circ} \mathrm{C}\left(77.0^{\circ} \mathrm{F}\right)$. [14]. 


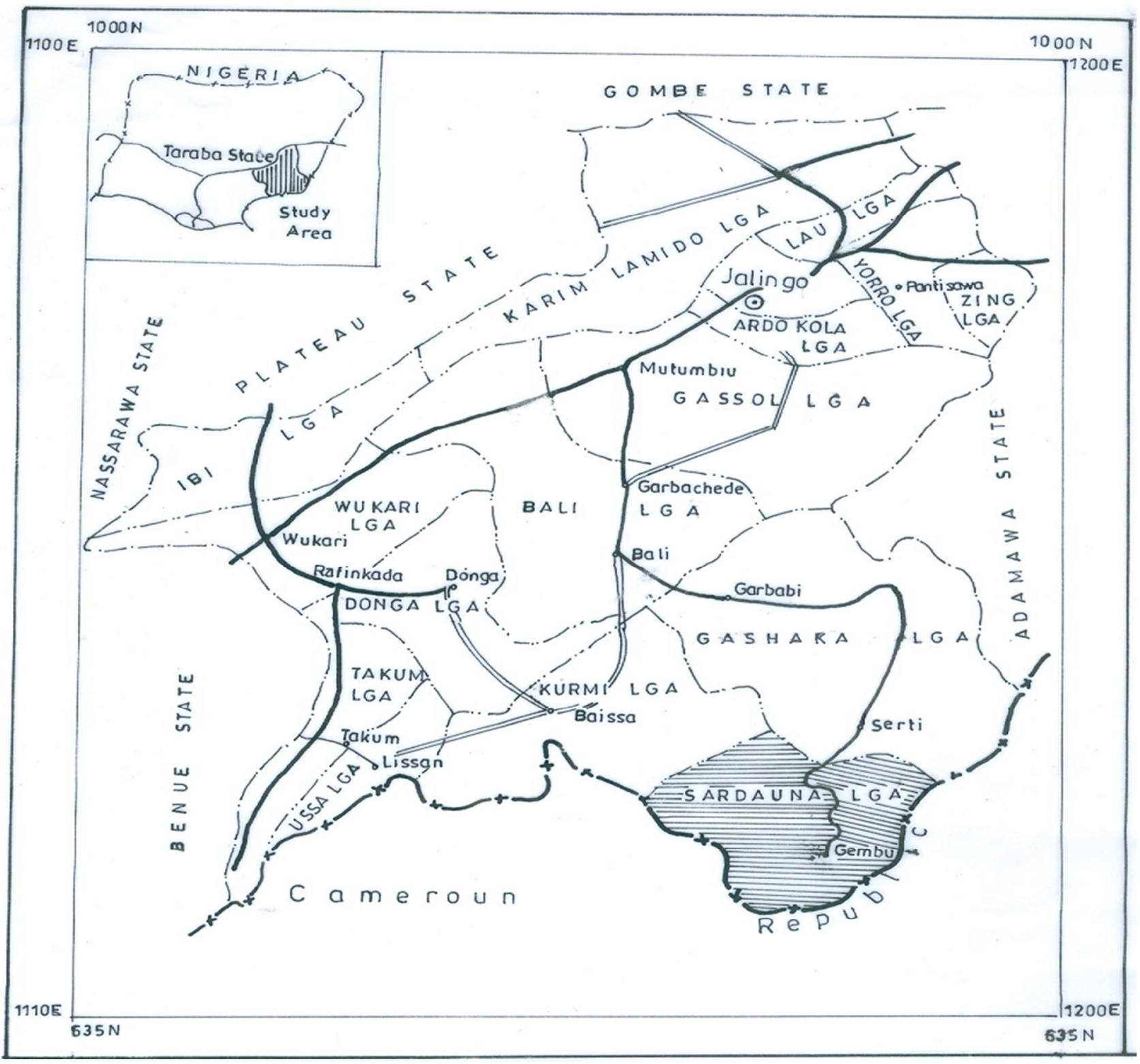

Figure 1. The map of Taraba State-Nigeria, showing the study area.

\subsection{Sampling and Sample Preparation}

The methods of Virendra and Agrawal [16], ISO [17], Rayment and Higginson [8] were used with some modifications in the process of soil sampling. Samples of soils were collected starting from the foot of the mountain after clearing grasses with cutlass, the digging was done with a simple hoe at $(0-25) \mathrm{cm}$ depth, and a ruler used for the measurement. For each location, three soil samples weighing about $500 \mathrm{~g}$ were collected at three random points using the corer. Sampling began from Mayo-Selbe Village, at a distance of $3 \mathrm{~km}$ interval moving through hilly parts with deep gorges from one panoramic view to the other, to the first tip settlement Maisamari village. The sampling process continued through Nguroje, Yelwa, Lekkitaba, Mayondaga, Tunga Shaibu, Kakara, Mbamga, Mayodale, Papa settlements and Gembu town. A total of twelve settlements with thirty six (36) bulk samples was collected, bagged in clean dry polyethylene and transported to the laboratory. The pre analysis treatment of all the bulk samples collected was done immediately at the laboratory. All particles in the soils like stones, pieces of wood, particle rocks, gravels, organic debris were removed. The soils were sieved through a $2 \mathrm{~mm}$ mesh, mixed and quartered to obtain a total of (12) representative samples one for each location, oven dried and finally introduced into a clean dry polyethylene bag $[17,18]$. The soil samples were coded and labelled as follows: The northern settlements $N_{1}, N_{2}, N_{3}, N_{4}$; eastern settlements $E_{1}$, $E_{2}, E_{3}, E_{4}$ while the southern part are $S_{1}, S_{2}, S_{3}$, and $S_{4}$ respectively. 


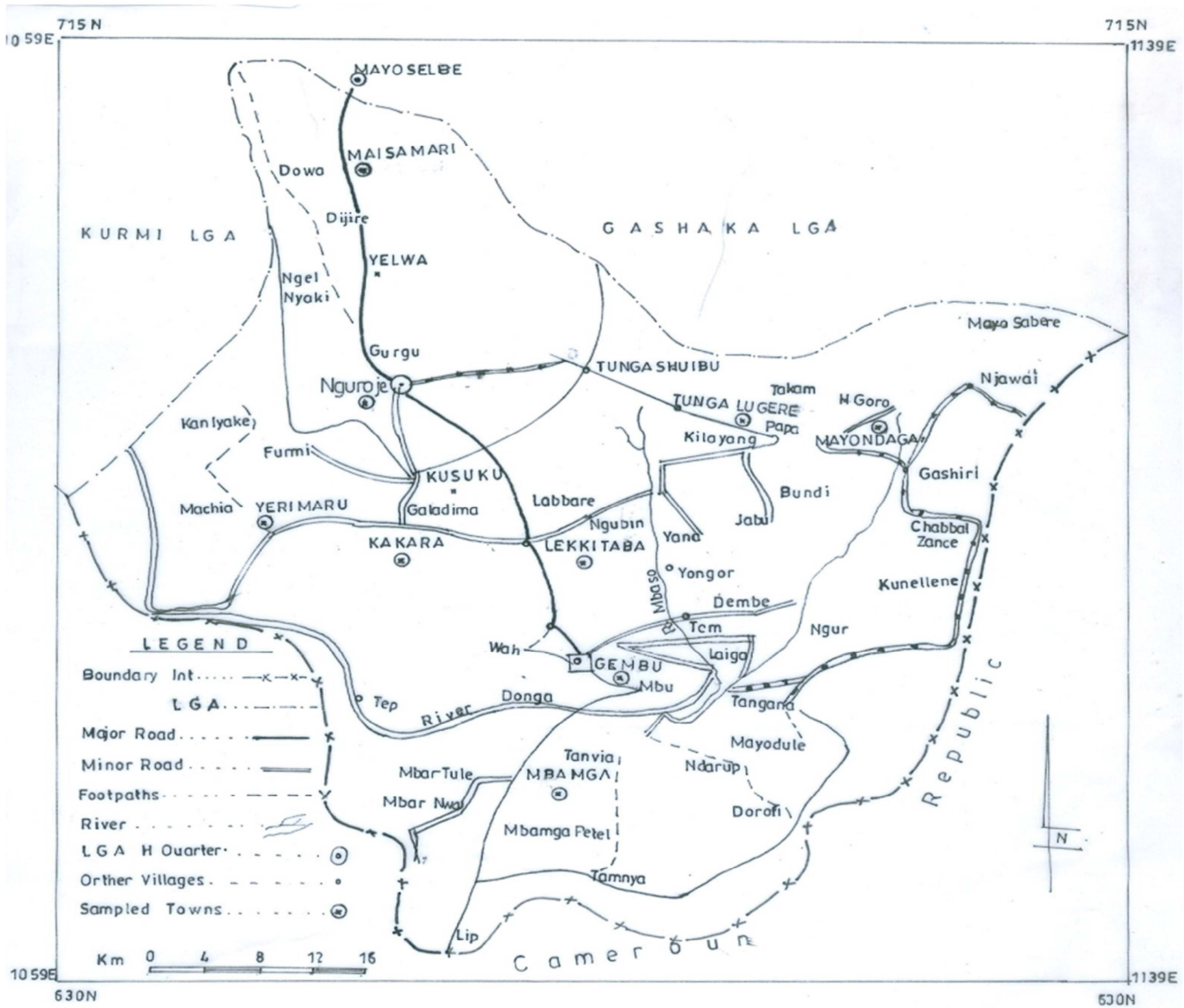

Figure 2. Map of study area showing the sampled locations.

\subsection{Determination of Soil Colour and Analytical Studies of Soil}

The colour of each soil sample was determine by comparing the soil colour in its field condition to a series of colour clips in a booklet called soil colour chart using the methods of Munsell. [19, 20]. Each chip was describe uniquely by its position on the three axes of colours; hue or spectral colour, value or degree of darkness, and chroma, purity or strength of colour. The soil sample paste was held behind the page of the chips solute so that the soil colour matches any of the colours of chips seen through the holes punched on the page, then the colour that resonate was recorded as its colour both in name and standard notation.

\subsection{The pH Measurement}

The method of Onanuga and Shehzad et al. [21, 22] was adopted, about $5 \mathrm{~g}$ of each air-dried and sieved soil samples were added to $40 \mathrm{~cm}^{3}$ distilled water and stir with glass rod for 5 minutes, for equilibration of the contents. The sensio $\mathrm{pH}$ meter was standardized using standard buffer 4.0, 7.0 and 10.0 at $25^{\circ} \mathrm{C}$ with an accuracy of $\pm 0.02 \mathrm{pH}$ units for the electrode calibration. The $\mathrm{pH}$ of the aqueous sample suspension was read off after inserting the sensio $\mathrm{pH}$ meter electrode into each soil suspension and gently swirling the beaker so as to ensure accurate reading from equal surrounding condition. The reading was taken after it had attained stability, and test were repeated to obtain an average data of three readings at $25^{\circ} \mathrm{C}$.

\subsection{Electrical Conductivity Measurement}

This was carried out as described by Onanuga and Shehzad et al. [21, 22]. The Sensio electrical conductivity meter was checked and the electrode cleansed using distilled and deionized water, and dipped into the aqueous sample solution to test for dissociated charge ions present. The reading were then taken at a time the pointer becomes steady. All readings were replicated trice to obtain average 
value.

\subsection{Specific Gravity Measurement}

The specific gravity of the sample was determined using a specific gravity bottle as describe by a bureau of Indian standards [17, 23]. About 12 grams of the sample was used. The specific gravity of the sample was calculated from using the formula below:

$$
\mathrm{S} . \mathrm{G}=\left(\mathrm{W}_{2}-\mathrm{W}_{1}\right) /\left[\left(\mathrm{W}_{4}-\mathrm{W}_{1}\right)\left(\mathrm{W}_{3}-\mathrm{W}_{2}\right)\right]
$$

Where $\mathrm{W}_{1}$ weight of bottle; $\mathrm{W}_{2}$ weight of bottle + sample; $\mathrm{W}_{3}$ weight of bottle + sample + water; and $\mathrm{W}_{4}$ weight of bottle + water.

\section{Results and Discussions}

Table 1. Physicochemical properties of soil samples collected.

\begin{tabular}{|c|c|c|c|c|c|}
\hline Location code & Soil colour & Standard Notation & Specific gravity & pH & Conductivity $\mathrm{mS} / \mathrm{cm}$ \\
\hline $\mathrm{E}_{1}$ & $\mathrm{drb}$ & $5 Y R 3 / 4$ & 2.21 & 4.12 & 93.0 \\
\hline $\mathrm{E}_{2}$ & $\mathrm{rb}$ & $5 Y R 5 / 4$ & 2.12 & 4.26 & 89.30 \\
\hline $\mathrm{E}_{3}$ & $\mathrm{~b}$ & $7.5 \mathrm{YR} 4 / 4$ & 2.33 & 4.24 & 153.60 \\
\hline $\mathrm{E}_{4}$ & $\operatorname{drg}$ & $5 \mathrm{YR} 4 / 2$ & 2.50 & 4.11 & 136.70 \\
\hline Range & & & $2.12-2.50$ & $4.11-4.26$ & $89.30-153.60$ \\
\hline Mean SD & & & $2.29 \pm 0.14$ & $4.18 \pm 0,07$ & $118.15 \pm 29.68$ \\
\hline $\mathrm{N}_{1}$ & Ig & $10 \mathrm{YR} 7 / 2$ & 2.35 & 4.52 & 238.00 \\
\hline $\mathrm{N}_{2}$ & $\mathrm{drb}$ & $5 Y R 3 / 4$ & 2.00 & 3.93 & 183.20 \\
\hline $\mathrm{N}_{3}$ & $\mathrm{yr}$ & $5 Y$ Y 5/6 & 2.09 & 4.09 & 174.30 \\
\hline $\mathrm{N}_{4}$ & $\mathrm{rb}$ & $5 Y R 5 / 4$ & 2.31 & 3.62 & 93.00 \\
\hline Range & & & $2.00-2.35$ & $3.62-4.52$ & $93-238.00$ \\
\hline Mean SD & & & $2.19 \pm 0.15$ & $4.04 \pm 0.32$ & $172.13 \pm 57.78$ \\
\hline $\mathrm{S}_{1}$ & wr & $2.5 \mathrm{YR} 5 / 2$ & 2.24 & 4.29 & 81.79 \\
\hline $\mathrm{S}_{2}$ & $\mathrm{yr}$ & $5 Y R 5 / 6$ & 2.36 & 4.30 & 101.90 \\
\hline $\mathrm{S}_{3}$ & $\mathrm{~g}$ & 5YR6/1 & 2.39 & 4.16 & 120.10 \\
\hline $\mathrm{S}_{4}$ & $\mathrm{sb}$ & $7.5 \mathrm{YR} 5 / 6$ & 2.37 & 3.96 & 100.20 \\
\hline Range & & & $2.24-2.39$ & $3.96-4.30$ & $81.79-120.10$ \\
\hline Mean SD & & & $2.34 \pm 0.09$ & $4.18 \pm 0.13$ & $100.10 \pm 46.17$ \\
\hline
\end{tabular}

$\mathrm{b}=$ brown; $\mathrm{drb}=$ dark reddish brown; drg $=$ dark reddish gray; $\mathrm{g}=$ gray; $\mathrm{lg}=$ light gray; $\mathrm{sb}=\mathrm{strong}$ brown; $\mathrm{rb}=\mathrm{reddish}$ brown; $\mathrm{wr}=\mathrm{we}$ eak red; $\mathrm{yr}=\mathrm{yellow}$ red;

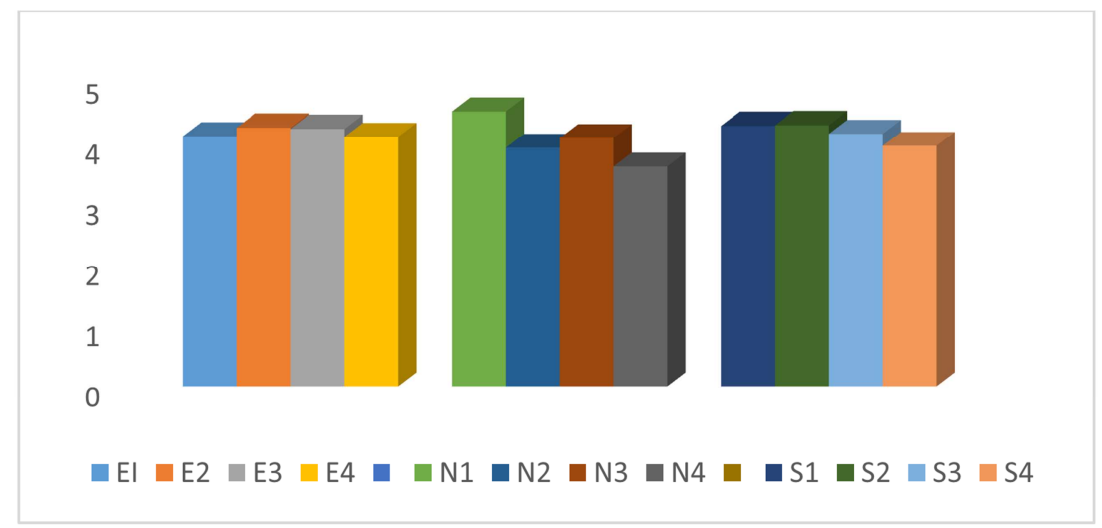

Figure 3. The pH values for soils. 


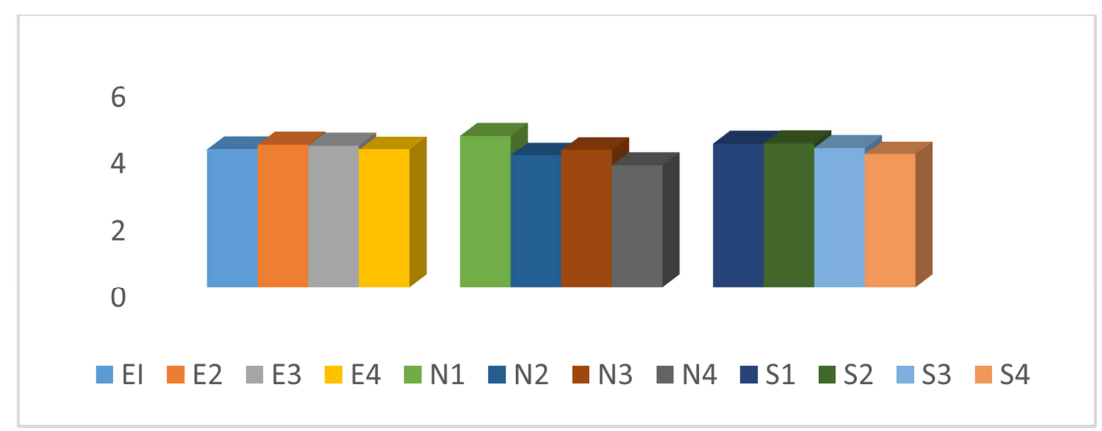

Figure 4. The values for specific gravity of soils.

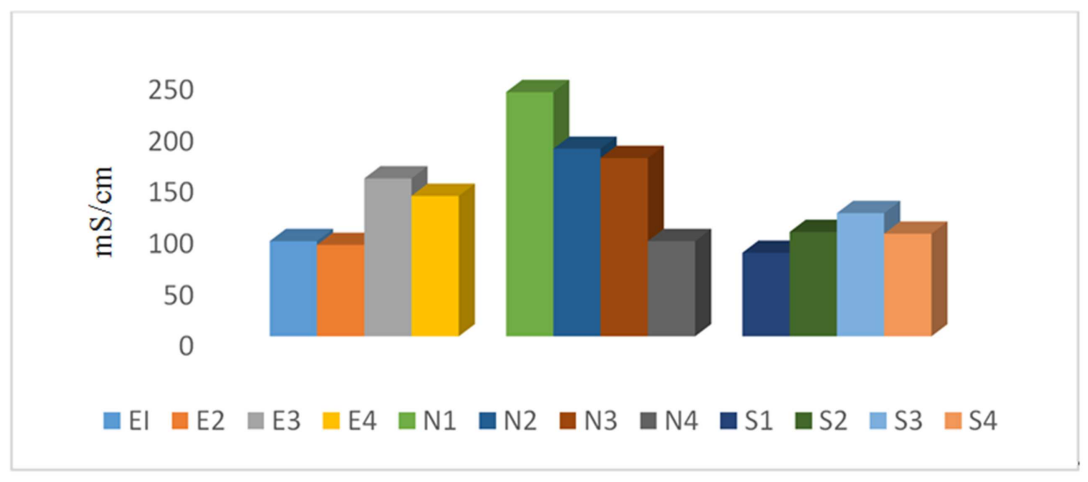

Figure 5. The values of electrical conductivity of the soils in $\mathrm{mS} / \mathrm{cm}$.

\subsection{Physicochemical Properties}

Table 1 present the physicochemical properties of the sampled soils studied. The colour of the soil varied from yellow to red and gray with soil hues of $2.5 \mathrm{YR}, 5 \mathrm{YR}, 7.5 \mathrm{YR}$ and 10YR. The entire soil also showed value of 3 to 7 and chroma range of 1- 6. The soil colour of eastern samples points showed the hue difference of one unit (2.5) interval at $\mathrm{E}_{3}$ 7.5YR4/4 against $\mathrm{E}_{1} 5 \mathrm{YR} 3 / 4, \mathrm{E}_{2}$ 5YR5/4 and $\mathrm{E}_{4}$ 5YR4/2 that are all reddish yellow in standard notation, the hue is 5 , value is $3-5$ and chroma 2,4 . The ordinary mixed brown colours of dark reddish brown, reddish brown, brown and dark reddish gray of these soils sampled were perhaps due to high presence of magnetite content in the soil. [24]. Likewise the northern sampled points had a hue 5 and 10 , value 3,5 , and 7 and chroma 2, 4, and 6 with mixed colours. $\mathrm{N}_{1}$ 10YR7/2 showed gray colour, $\mathrm{N}_{2} 5 \mathrm{YR} 3 / 4$ indicated dark reddish brown, as sample $\mathrm{N}_{3} 5 \mathrm{YR} 5 / 6$ is yellowish red, $\mathrm{N}_{4}$ 5YR5/4 was reddish brown. The Samples $\mathrm{S}_{1} 2.5 \mathrm{YR} 5 / 2$ and $\mathrm{S}_{2}$ $5 Y R 5 / 6$ were, weak red and reddish yellow colours respectively. $\mathrm{S}_{3} 5$ YR6/1 was gray, but $\mathrm{S}_{4} 7.5 \mathrm{YR} 5 / 6$ strong brown. The hue is $2.5,5$ and 7.5, value is between 5, 6 and chroma 1, 2 and 6 respectively. The yellow and reddish colours displayed by some samples may be due to high iron oxides present in the soil samples. $[25,26]$. The development and distribution of colours may be due to the extensive and various minerals that results from chemical and biological weathering, especially redox reaction. The primary minerals in soil parent material are weathered and thus the elements combine into new and colourful compounds, forming secondary minerals with a yellow or red colour, the soil organic matter also decomposes into black and brown compounds. [27]. Based on these results, the difference in hue chroma is by 1 and 2 that indicates the chroma contrast as prominent as classified by Munsell. [20]. Figure 3 present the $\mathrm{pH}$ of soils from all sampled points analyzed for the study, gave an entire range of $\mathrm{pH} 3.62-4.52$. The eastern locations have $\mathrm{pH}$ range between 4.11-4.26 at $\mathrm{E}_{1}-\mathrm{E}_{4}$, with an average of 4.18. The northern samples are a range of $\mathrm{pH}$ 3.63-4.52 with mean value of 4.04 also indicating strong acidic soil. The southern soil samples are also acidic with a $\mathrm{pH}$ range of 3.96-4.30. The result of this study is in tandem with a $\mathrm{pH}$ of 4.44-5.59 reported by Imadojemu et al. [28]. Jarrod [29] reported that, a mineral soil of $\mathrm{pH}$ 6.0-7.0 and $\mathrm{pH}$ 5.5 for organic soils will be good for most agricultural crops. Furthermore, soils with high acidity can lead to toxic amounts of aluminium and manganese. Haynes and Naidu [30], also reported that soil $\mathrm{pH}$ has effects on plant growth, metal ion solubility, microbial activity and clay dispersion. Moeckel et al. [26] established that, water moving through the soil removes the bases compounds and substitutes them with hydrogen ions making the soil acidic and unsuitable for agriculture as a result of the leaching process. It was observed that the low farming activities in the area could be attributed to the soil status. In Figure 4, generally the values for electrical conductivity of the soil samples tested showed the lowest and highest conductivity range of $81.79-238$ $\mathrm{mS} / \mathrm{cm}$ respectively. The Electrical conductivity is a numerical expression of the ability of an aqueous solution to carry an electrical current at equilibrium in a water suspension of soil, sludge or bio-waste. [31]. The eastern sampling points $E_{2}, E_{3}$ yield a minimum conductivity of $89.30 \mathrm{mS} / \mathrm{cm}$ and a maximum of $153.60 \mathrm{mS} / \mathrm{cm}$. The 
northern location is the most conductive with $\mathrm{N}_{1}$ tested 238 $\mathrm{mS} / \mathrm{cm}$ and $\mathrm{N}_{4} 93 \mathrm{mS} / \mathrm{cm}$. In the southern parts $\mathrm{S}_{1}$ is 81.79 $\mathrm{mS} / \mathrm{cm}$ while $\mathrm{S}_{3}$ gave $120.10 \mathrm{mS} / \mathrm{cm}$. Reihm et al. [32] emphasized that, the guideline for a suitable electrical conductivity that support productive soil is between 200$1200 \mathrm{mS} / \mathrm{cm}$. Similarly Pravin et al. [33] stated that soil conductivity correlates with soil properties that affect soil texture, organic matter level, crop productivity, cation exchange capacity, drainage conditions and salinity, and subsoil characteristics. In addition soil with conductivity less than $200 \mathrm{uS} / \mathrm{cm}$ will have no enough elements to support crop production; thus show a sterile soil with little microbial activity. [34, 35, 36]. On the other hand, Oleveira et al. [37] relates that when soil conductivity is greater than $3000 \mathrm{uS} / \mathrm{cm}$ is saline. Figure 5 illustrates the specific gravity of the soils ranging from $2.00 \mathrm{~g} / \mathrm{cm}^{3}$ to $2.500 \mathrm{~g} / \mathrm{cm}^{3}$, with mean values of $2.29 \pm 0.14$ from the eastern sample locations; $2.19 \pm 0.15$ from the northern sample locations and $2.34 \pm 0.09$ in the southern sample points respectively. In a study on soils of Morbi, Khorajiya et al. [38] stated a lower values of bulk density1.20-1.66 g/ $\mathrm{cm}^{3}$ and higher values for the particle density of the sampled soils between 2.04 to $3.44 \mathrm{~g} / \mathrm{cm}^{3}$, This result agrees with the specific gravity of soils made up of mineral particles with very low organic matter content stated by Sarka et al. [24].

Table 2. Percentage (\%) concentration of trace elements in soils.

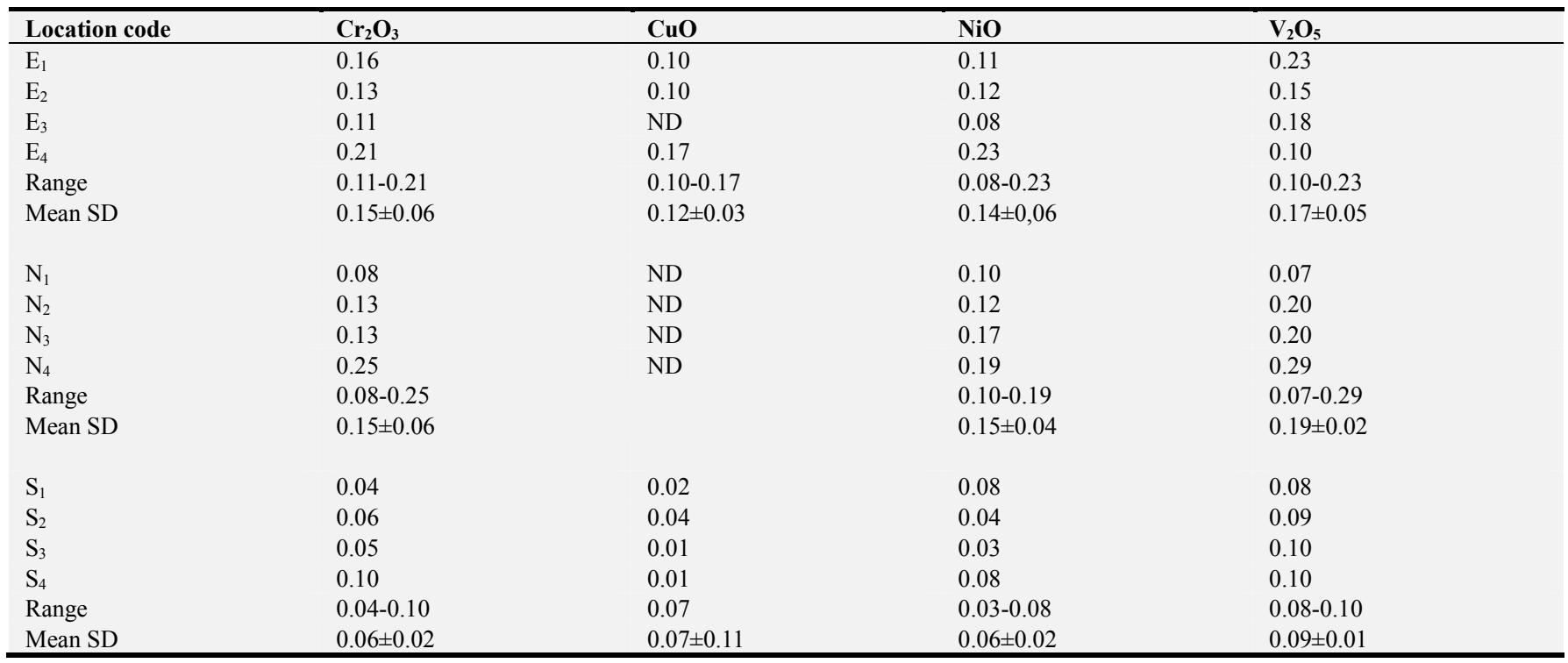

Detection: limit $>0.001 ; \mathrm{ND}=$ Not Detection; $\mathrm{SD}=$ Standard deviation

\subsection{Percentage Concentrations of Trace Elements}

Table 2 shows the trace elements analyzed at various samples sites. The trace metal oxides detected in this study were $\mathrm{Cr}_{2} \mathrm{O}_{3}, \mathrm{CuO}, \mathrm{NiO}$ and $\mathrm{V}_{2} \mathrm{O}_{5}$. The concentration of trace elements in this study indicated decreased order from vanadium with the highest concentration $\mathrm{V}_{2} \mathrm{O}_{5}>\mathrm{CrO}_{3}>\mathrm{NiO}>\mathrm{CuO}$ to copper showing the minimum concentration. However, other elements like $\mathrm{Pb}, \mathrm{Cd}, \mathrm{Hg}, \mathrm{As}$, $\mathrm{Zn}$ were not detected in any of the samples studied; perhaps their availability might be at low concentration that are below detection limit of the instrument used for the analysis. One possible explanation is that the high $\mathrm{pH}$ level of the soil could have reduced their presence through precipitation or complex formation with Fe-Mn oxyhydroxides. [39]. As seen in Figure 6 above, the concentration of chromium detected in the samples was in the range $0.04 \%-0.25 \%(400-2500$ $\mu \mathrm{g} / \mathrm{g})$. The percentage mean concentrations for $\mathrm{Cr}$ were $0.15 \% \pm 0.06(1500 \mu \mathrm{g} / \mathrm{g})$ in both eastern and northern locations. While $\mathrm{N}_{4}$ showed the highest concentration at $0.25 \%(2500 \mu \mathrm{g} / \mathrm{g}), \mathrm{S}_{1}$ was the lowest $\mathrm{Cr}$ concentration with $0.04 \%(400 \mu \mathrm{g} / \mathrm{g})$. These are higher than the $(11,50,100$, $150,250) \mathrm{mg} / \mathrm{kg}$ stipulated standards on agricultural soil by
US EPA [40], EPAA [41], WHO [42], EU [43], and CME [44] respectively. Similarly, Lago-Vila et al. [45] on analysis of quarry site soil stated a higher $\mathrm{Cr}$ level $1300 \mu \mathrm{g} / \mathrm{g}$ in a studied soil. Fosu-Mensah et al [46] on the contrary established a lower chromium level $56.0 \pm 1.15 \mu \mathrm{g} / \mathrm{g}$ in soils and vegetation of Korle lagoon. Sexana [27] observes that soils contamination could be attributed to the parent materials of the soils. This reflects contamination from non-irrigated sources from soil parent material, minerals waste derived fertilizers and some fungicides/pesticides commonly applied in agricultural practices around the areas [10, 36, 47, 48].

Figure 7 shows the concentration of copper analysed in the sampled locations ranging from $0.01 \%-0.17 \%$ (100$1700 \mu \mathrm{g} / \mathrm{g})$. This element recorded significant lower levels of detection compare to other elements in the study, as seen evident by negligible or below detection concentration from the samples sites at $\mathrm{N}_{1}-\mathrm{N}_{4}$ and $\mathrm{E}_{3}$. The samples $\mathrm{S}_{4}$ and $\mathrm{S}_{3}$ measured $0.01 \%(100 \mu \mathrm{g} / \mathrm{g})$ as that was within the guidelines of $\mathrm{FAO} / \mathrm{WHO} / \mathrm{EU}[49,42,43]$. The concentrations of copper at $S_{1}, S_{2}, E_{1}, E_{2}$ and $E_{4}$ indicated $(200<400<1000<1700) \mu \mathrm{g} / \mathrm{g}$ accordingly was higher than the guidelines for $\mathrm{Cu}$ in agricultural soils, also higher value of $\mathrm{Cu} 12,000 \mathrm{ug} / \mathrm{g}$ was 
reported [45] in serpentinite quarry. The average concentration of the availability of copper in the soil may be also as a function of the soil $\mathrm{pH}$ and texture [26]. The finertexture mineral soils generally contain the highest amount of copper, the lowest concentrations are associated with the organic or peat soils. Therefore, as soil $\mathrm{pH}$ increases, the availability of these nutrients decreases [24].

Figure $8 \mathrm{Nickel}$ was also detected in all samples in a range $0.03 \%-0.23 \%(300-2300) \mu \mathrm{g} / \mathrm{g}$. The concentration were higher in most samples from $\mathrm{N}_{1}-\mathrm{N}_{4}$ and $\mathrm{E}_{1}-\mathrm{E}_{2}$. The location $\mathrm{E}_{4}$ yielded the highest $2300 \mathrm{~g} \mu / \mathrm{g}$ of $\mathrm{Ni}$ analyzed, while $\mathrm{S}_{3}$ was low at $300 \mu \mathrm{g} / \mathrm{g}$. These concentrations are all above the established guidelines for nickel 45-50 $\mu \mathrm{g} / \mathrm{g}$ levels in agricultural soil [42, 43, 44].

Figure 9 presents the concentration of vanadium between $0.07-0.29 \%(700-2900) \mu \mathrm{g} / \mathrm{g}$. The study revealed $\mathrm{N}_{4}$ sample with $2900 \mu \mathrm{g} / \mathrm{g}$, as the highest concentrations of an element detected and $\mathrm{N}_{1} 700 \mu \mathrm{g} / \mathrm{g}$ as the least of vanadium in this study. These values exceeded the FAO established allowed limits of vanadium $75 \mu \mathrm{g} / \mathrm{g}$ in agricultural soil [49]. Other studies that established levels of vanadium above threshold includes, Rasheed et al. [50] reported $490 \mu \mathrm{g} / \mathrm{g}$, Jayawardana et al gave $820 \mu \mathrm{g} / \mathrm{g}$ [51], and Hernandez and Rodriguez stated $645 \mu \mathrm{g} / \mathrm{g}$ of vanadium accordingly [52]. Manga et al. stated $654 \mu \mathrm{g} / \mathrm{g}$ [53] Kabata-Pendias wrote $460 \mu \mathrm{g} / \mathrm{g}$ as highest vanadium level in metal soil investigation studied. [54]. They further stated, that the behaviour of trace metals in soil environment also depend on their origin due to pedogenic process that transformed lithogenic and anthropogenic metals, which are greatly control by soil properties. In addition, vanadium amounts in soils such as loamy and silty as well as ferallistic can be above that of parent materials [54]. The high content of trace elements detected in the studied samples so far are indications of a mineralized bedrocks occurrence of ores resulting to the geogenic anomalies in the soil, Alloway [55], or in binding nature with other minerals like bauxite and carnotile [56]. Therefore, the appreciable excess concentration of these trace elements studied, will have toxic effects and posed human health risks on other sources like groundwater used and plants grown in those locations.

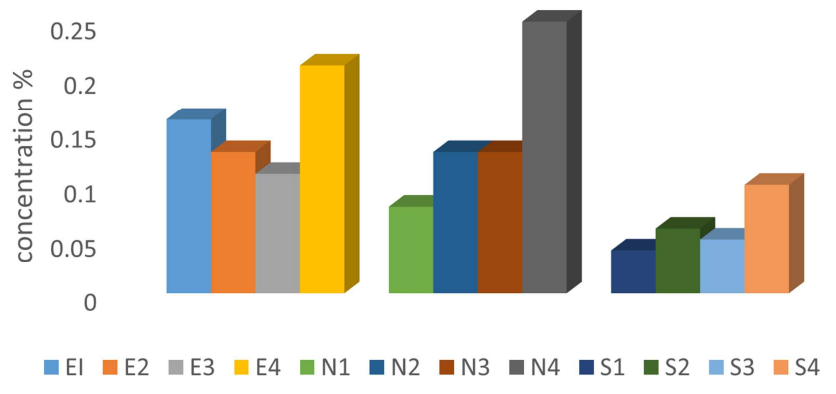

Figure 6. Percentage concentration of $\mathrm{Cr}_{2} \mathrm{O}_{3}$ in soil.

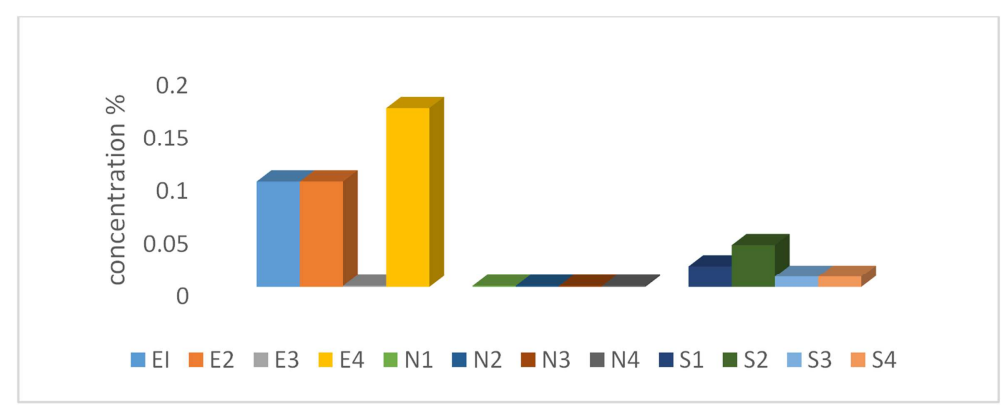

Figure 7. Percentage concentration of $\mathrm{CuO}$ in soils.

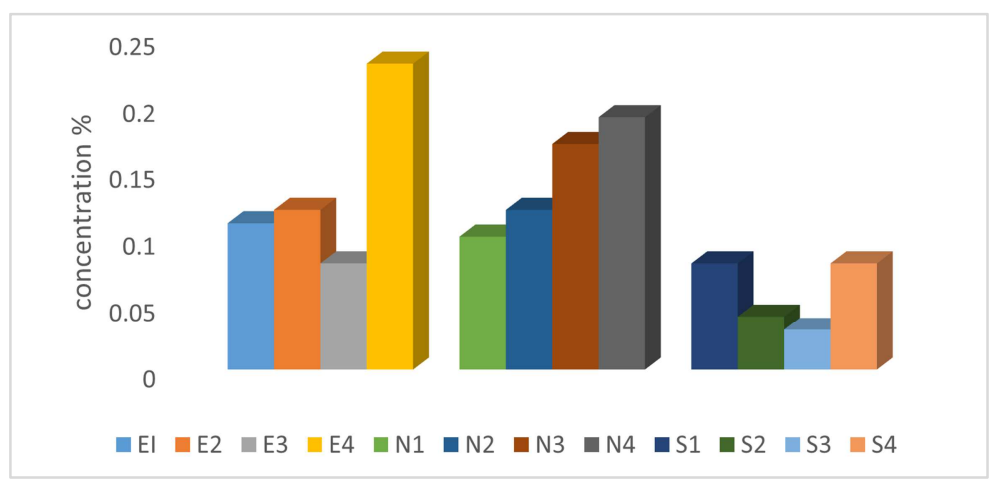

Figure 8. Percentage concentration of $\mathrm{NiO}$ in soils. 


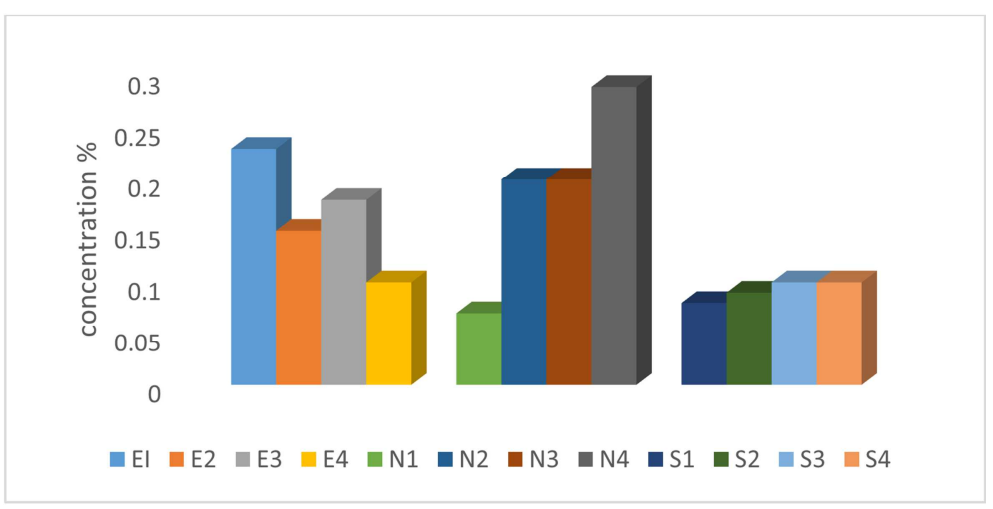

Figure 9. Percentage concentration of $\mathrm{V}_{2} \mathrm{O}_{5}$ in soils.

\subsection{Statistical Data Analysis}

The data analyzed at $F_{3,39}=2.85 \mathrm{p}<0.05$. There is no significant variations in the elements concentration and the $\mathrm{pH}$ of the studied soils.

\section{Conclusion}

From this study, the following conclusions can be drawn from data of the physicochemical parameters of the soil samples obtained in this study; colour, $\mathrm{pH}$, specific gravity and electrical conductibility showed that the Mambilla plateau was developed on a highly weathered soil. This may in other way, decrease its organic matter content owing to the soil acidic $\mathrm{pH}$ which may greatly decreased the availability of soluble bases such calcium, magnesium, potassium and nitrogen in the soil. The trace elements analyzed were absent in some of the soil samples which perhaps is due to their trace amounts in the location below the detection limit of the instrument used, or as a result of scavenging capabilities of other minerals. The soil formed on the plateau is generally slightly acidic and has high amounts of all the detected elements beyond guidelines may be toxic to plants and human health. The observed stunted growth in plants cultivated, low grasses as if they were trimmed and poor agricultural yields in the area is an indication of poor soil fertility. In addition, further study be conducted to assess the bioavailability and potential human risks of the soil components in the environment as it relates to sources of groundwater and presence in plants cultivated in the locations.

\section{References}

[1] Ayoub A. S, McGaw B. A, Shand C. A, Midwood A. J (2003). Photoavailability of $\mathrm{Cd}$ and $\mathrm{Zn}$ in soil estimated by stable isotope exchange and chemical extraction. Plant and Soil Vol. 252 No. 2, 291-300.

[2] Raymond R. Weil, Nyle C. Brady (2016). Nature and Properties of Soils. $15^{\text {th }}$ Edition. Pearson Education. Columbus.

[3] Abaje I. B (2007). Introduction to soil and vegetation. Personal Touch Productions, Kaduna. 1-56.
[4] Raji, B. A., Chude, V. O. (2007). "Compilation of Existing Soil Series in North-Western Nigeria" Department of Soil Sevens. Ahmadu Bello University Zaria, Nigeria.

[5] Fasina, S. A. (2004), "Influence of Land Utilization of an altisol in South-Western Nigeria", Journal of Sustainable Agriculture and Environment 6 (2): 171-178.

[6] Amoyou U. A, Eze E. B, Essoka P. A, Effiong J, Egbai O. O (2013). Spatial variability of soil properties in Obudu Mountain Region of southeastern Nigeria. International Journal of Humanities and Social Science Vol. 3 No. 145-149.

[7] Owonubi, A., Raji, B. A. and Odunze, A. C. (2006), "Morphological and physical properties of soils of a Toposequence in Samaru", Zaria, Ahmadu Bello University, Nigeria.

[8] Udo, B. I., Ndaeyo N. U. and Harold, K. O. (2006), "Fertility Status and Variability of some soil Developed from different parent materials in the humid region of Nigeria. Department of soil science, University of Uyo, Nigeria.

[9] Stolt, M. H. Bake, J. and Simpson, T. W. (1993), "Soil Landscape Relation in Virginia". Soil Science Society, American Journal of Soil 57: 414 - 420.

[10] Mokuna, D. L. (1987), "Soil Variability of five Landforms in Michigan”. Soil Survey and Evaluation 7 (1): 25 - 30.

[11] Yu, K. N., Yeung, Z. L. L, Lee, L. Y. L. Stokesa, M. J. and Kwok, R. C. W (2002). Determination of Multi-element profiles of soil using energy dispersive X-ray fluorescence (EDXRF), Appl. Radiat. Isot. 57, 279-284.

[12] Buol, S. W., Hole, F. D. and McCracken, R. J. (1973), "Soil Genesis and Classification $1^{\text {st }}$ edition, Ames, I. A: Iowa State University Press 15BN 0-8138-1460-X.

[13] Boul, W. Stanley, Randall J. Southhard, Robert C. Graham, Paul A. McDaniel (2003). Soil genesis and classification. $5^{\text {th }}$ Edition. Wiley Publication.

[14] Bami Yuno (2013). The Mambilla Region in African History (ms ed) Nzikachia: Unpublished p360.

[15] Mambilla Plateau (2011). Nigeria Online Tourism Magazine. GggGoodlife.com.ng.

[16] Virendra Singh, H. M. Agrawal (2012). EDXRF Analysis of Soil Samples to Study the Role of Trace Elements in Optimizing the Yield, International Journal of Modern Engineering Research (IJMER) Vol. 2, Issue. 4, 1454-1458. 
[17] ISO (2006) ISO 11464 (2006) Soil quality-pretreatment of samples for physico-chemical Analysis.

[18] Rayment, G. E., Higginson, F. R. (2002). Australian Laboratory Handbook of Soil and Water Chemical Methods, Melbourne, Inkata Press.

[19] Munsell, (1973), "Munsell soil Colour Chart" Machetch Division of Kollomorgen Corporation Baltimore, Maryland 21218, USA.

[20] Munsell, (2009), Soil Colors charts with genuine Munsell color chips, Produced by Munsell color, $430044^{\mathrm{TH}}$ street Grand Rapids MI, 49512.

[21] Onanuga, K. V. (2008), "Chemical Analysis of Nutrients and Pollutant Elements Contents of soils in two commercial farms in Adamawa state", Federal University of Technology Yola, Nigeria. Unpublished M-Tech Thesis.

[22] Shehzad Ahmed, Hameed-ur-Rehman, Baharullah, Khattak, Nisar Ahmad, Anum Urooj, Noor Ul Akbar, Muhammad Masab, Wajid Ullah, Ali Rehman and Azam Khan Durrani (2015). Soils of an European Mediterranean area by multivariate analysis. Chemosphere 65:863-872.

[23] ASTM (2008) C127 - 15 Standard Test Method for Relative Density (Specific Gravity) and Absorption of Coarse Aggregate, ASTM International, West Conshohoken, PA, 2015, http://www.astm.org/cgi-bin/resolv.

[24] Sarka, J. P. Landey, R. J. Kalbande, A. R. and Mondol, C. (2011). Characteristic and Classification of Soils of Kathiawar Region of Gurarat as influenced by Topography. Agropedology, Journal of Soil Science, Ahmadu Bello University, Zaria, 83-90.

[25] Brady N. C and Weil, R. R. (2003)."The Nature and Properties of Soils," Pearson Education (Asia).

[26] Moeckel C., Nizzetto L., Di Guardo A., Steinnels E., Freppas M., Filippa G., Camporini P., Benner J., Jones, K. C. (2008), "Persistent Organic Pollutants in Boreal and Mountane Soil Profile distribution, evidence of processes and implications for cycling" Journal of Environmental science and Technology 42 (22): $8374-8380$.

[27] Sexana, M. M. (1990), Environmental Analysis of Water, Soil and Air. Agro Botanic Publisher New Delhi, India pp121-129.

[28] Imadojemu P. E, Usojuike D. N, Obasi S. N, Mbe J. O, Dibofori E. G (2018). Characterization and Classification of some soils of Edo State formed under different parent materials. FUW Trends in Science and Technology Journal Volume 3, No. 1, 201-206.

[29] Jarrod O. Miller (2016). Soil pH affects nutrient availability. University of Maryland Extension15http://www.extension.umd.edu.

[30] Haynes, R. J., Naidu, R (1998). Influence of lime, fertilizer and manure applications on soil organic matter content and soil physical conditions: A review. Nutritional Cycle Agroecosystem 51, 123-137.

[31] Hanlon E. A CIR10801 (2015). Soil pH and Electrical Conductivity: A country Extension soil Laboratory Manual. University of Florida IFAS Extension. http://edis.ifas.uf/.edu Retrieved May, 2017.

[32] Rehm, G. M.; Schmith, H. J.; Lamb, R. E. (2001). Fertilizer recommendation for agronomic Crops in Minnesota. University of Minnesota Extension publication. 134-240.

[33] Pravin R. Chaudhari., Dodha V. Ahire., Manab Chkravarty., Saroj Maity (2014). Electrical Conductivity as a Tool for Determining the Physical Properties of Indian Soils. International Journal of Scientific and Research Publications, Volume 4, Issue 4, 1-4.

[34] Arshad, M. A. and Martin, S. (2002) Identifying critical limits for soil quality indicators in Agro-ecosystems. Agriculture, Ecosystems and Environment. 88:153-160.

[35] Eshani, R. and Sullivan, M. (2006), Electrical Conductivity (CE) sensor, Ohio State University Extension, AEX 562-02 http://ohioline.OSU.edu/aex-fact/0565.pdf.

[36] Gaw S. K, Wilkins A. L, Kim N. D, Palmer G. T, Robinson P (2006). Trace elements and 2 DDT concentrations in horticultural soils from the Tasman, Waikato and Auckland regions of New Zealand. Sci Total Environ 355:31-47.

[37] Oliveira, F C; Mattiazzo, M E; Marciano, C R; Rossetto, R. (2002). Organic carbon, electrical conductivity, pH, and CEC changes in a typical hapludox after repeated amendments. Braz. J. Soil Sci. 26:505 - 519.

[38] Khorajiya, K. U., Kaneria, S. C., Jadeja, A. S., Chapadiya, F. and Rajani, A. V., Surendranath, R., Jawaharlal, M. and Anitha, K., (2017). Evaluation of Physical Properties of Irrigated Soils of Morbi District of Saurashtra Region of Gujarat Int. J. Pure App. Biosci. 5 (4):DOI:10.18782/23207051.5189 .

[39] Chuan M. C, Shu G. Y, Liu J. C (1996). Solubility of heavy metals in a contaminated soil: Effects of redox potential and pH. Water, Air and Soil Pollution. Vol. 90 No. 3-4, 543-556.

[40] United States Environmental Protection Agency (US EPA) (2012). Reviewed Supplemental guidance for developing soil screening levels for superfund sites. Office of Solid Waste and Emergency Response, Washington D. C http://www.epa.gov/perfund/health/conmedia/soil/index.htm.

[41] Environmental Protection Authority of Australia (EPAA) (2012). Classification and management of contaminated soil for disposal. Information Bulletin 105. Hobart, TAS 7001 Australia.

[42] World Health Organization (WHO) (2015). Global Health Observatory data repository. Burden of disease. Lead attributable daily. http://apps.who.int/gho/data/node.home.

[43] European Environmental Agency (EEA) (2007). Progress in management of contaminated sites (CSI 015/LSI 003, http://www.eea.europa.eu/data-and-maps/indicators.

[44] Canadian Ministry of the Environment (CME). (2009). Soil, Ground Water, Sediment Standards for use under Part XV. 1 of the Environmental Protection Act.

[45] M. Lago-Vila, D. Arenas-Lago, A. Rodríguez-Seijo, M. L. Andrade Couce, and F. A. Vega (2015). Cobalt, chromium and nickel contents in soils and plants from a serpentinite quarry. Solid Earth, 6, 323-335, DOI: 10.5194/se-6-323-2015.

[46] Benedicta Yahya Fosu-Mensah, Emmanuel Addae, Dzidzo Yirenya-Tawiah, Frank Nyame (2017). Heavy metals concentration and distribution in soils and vegetation at Koele Lagoon area Accra, Ghana. Cogent Environmental Science, 3, 1-14. DOI: $10.1080 / 23311843.2017 .1405887$. 
[47] Mico' C, Recatala' L, Peris M, Sa'nchez J (2006). Assessing heavy metal sources in Agricultural soils of an European Mediterranean area by multivariate analysis. Chemosphere $65: 863-872$.

[48] Tamene Fite Duressa, Seyoum Leta (2015). Determination of Levels of $\mathrm{As}, \mathrm{Cd}, \mathrm{Cr}, \mathrm{Hg}$ and $\mathrm{Pb}$ in Soils and Some Vegetables Taken from River Mojo Water Irrigated Farmland at Koka Village, Oromia State, East Ethiopia. International Journal of Sciences: Basic and Applied Research Volume 21, No 2, 352372 .

[49] Food and Agricultural Organisation FAO (2006): Guidelines for soil description, Food and Agriculture Organization of the United Nations, Rome.

[50] Rasheed M. A, Lakshmi M, Rao P. L. S, Kalpana M. S, Dayal A. M and Patil D. J (2013). Geochemical evidences of trace metal anomalies for finding hydrocarbon micro seepage in the petroliferous regions of the Tatipaka and Pasarlapudi areas of Krishna Godavari Basin, India. Pet. Sci. (2013) 10:19-29. DOI 10.1007/s12182-013-0245-x.

[51] Jayawardana D. T, Pitawala H. M. T. G. A, Ishiga H (2014). Geochemical evidence for the accumulation of vanadium in soils of chronic kidney disease areas in Sri Lanka. Environ Earth Sci. Vol. 73. Issue 9, 5415-5424. DOI 10.1007/s12665014-3796-2.

[52] Hernandez, H. \& Rodriguez, R. (2012). Geochemical evidence for the origin of vanadium in an urban environment. Environ Monit. Assess. Volume 184, Issue 9, 5327-5342 DOI/10.1007/s10661-011-2343-9.

[53] Veronica E. Manga, Christopher M. Agyingi, Cheo E. Suh (2014). Trace Elements Soil Quality Status of Mt. Cameroon Soils. Advances in Geology, volume 2014, 1-8 DOI/10.1155/2014/894103.

[54] Aliana Pendias-Kabata, Henryk Pendias (2001). Trace Elements in Soils and Plants. Third Edition CRC Press Boca Raton, London 239-249.

[55] Alloway B. J (2012). Heavy metals in soils: Trace Metals and metalloids in soils and their bio-availability. Third Edition. Springer Science.

[56] Merian, E., Anke, M., Ihnat, M and Stoeppler, M (2004). Elements and their Compounds in the Methods. Melbourne, Australia: Inkata Press. 145-148. 